\title{
Dynamics of Combined Oral Contraceptive: A Study of Some Haematological Parameters in Female Wistar Rats
}

\author{
Toryila J.E ${ }^{1}$, Amadi K ${ }^{2}$, Odeh S.O ${ }^{2}$, Adelaiye A.B ${ }^{1}$,Egesie U.G. ${ }^{2}$ Achie ${ }^{1} 1 \mathrm{~N}$ \\ Human Physiology Department, Faculty of Medicine, ABU, Zaria. \\ Human Physiology Department, Faculty of Medical Sciences University of Jos.
}

\begin{abstract}
Contraception is the intentional prevention of fertilization from taking place through the use of various devices, sexual practices, barrier methods and hormonal contraception. Contraception is as old as human existence.. Oral contraceptives are a simple form of contraception used by women worldwide. The oral contraceptive is one of the greatest and most influential developments of the twentieth century. Haematopoiesis is the process by which all lineages of blood cells are generated in a hierarchical and stepwise manner from immature cells present in the bone marrow (BM)' and subsequently released into circulating blood and peripheral organs for further maturation steps and/or effector function.Several haemorheological and haemostatic parameters has been associated closely with hormone replacement therapy. Such parameters include blood viscosity, plasma viscosity, haematocrit value, fibrinogen level and fibrinolytic activity. This research priority included efforts to discover the effect of COC (DUOFEM) on haematological parameters.
\end{abstract}

Method: Eighty (80) female wistar rats aged 10-12 weeks weighing 180-250 g were used for the study. They were divided into four groups of 20 rats each comprising 10 treated and 10 control rats. The treated rats received $0.6 \mathrm{mg} / \mathrm{kg}$ body weight of COC intragastically for 36, 48, 60 and 72 days in five-day cycles (four-days treatment with one-day break). The COC was given intragastically in 5-day cycles (4-day treatment with 1-day break). All controls were given fresh water at ad libitum daily for the period of the experiment.The blood sample was drawn into the test tube containing an anticoagulant (EDTA). A haematology analyzer was used to perform a complete blood count (CBC or FBC). It carries out quantitative and qualitative analyses of red and white blood cells and of platelets (erythrocytes, leukocytes and thrombocytes).

RESULTS: There were significant decreased in haemoglobin ( Hb, ),Packed cell volume (PCV),Red blood cell count $(R B C)$, White blood cell count (WBC), and Lymphocytesin treated groups, compared to the control $(P<0.05)$.There were significant increase in MCHC and $N$ in treated groups compared to the control $(P<0.05)$. There were however no significant changes in platelet count, MPV, MCV, MCH, M, N,E and B in treated groups compared to the control( $P<0.05)$.

KEYWORDS: Combined Oral Contraceptives, Haematological parameters, Wistar rats.

\section{INTRODUCTION:}

Contraception is the intentional prevention of fertilization from taking place through the use of various devices, sexual practices, barrier methods and hormonal contraception. Contraception is as old as human existence. For centuries, humans have relied on their imagination to avoid pregnancy. Oral contraceptives are a simple form of contraception used by women worldwide. The oral contraceptive is one of the greatest and most influential developments of the twentieth century. It is regarded as the most reliable method of contraception, and one of the easiest. They are widely available in most pharmacies and chemist shops. Oral contraceptives are highly reliable, non- permanent means of contraception after the rhythm method when correctly applied. Proper medication can achieve a successful rate of contraception as high as $98 \%$ or above (Beral, 1977).Global family planning programmes have been in existence in the developed world for several decades and are primarily designed to supply couples with the methods of family planning that best suit their needs. Birth control is a major factor in public health and welfare, preserving the general and reproductive health of women and allowing them to choose the movement of a planned pregnancy (WHO, 2007). The World Health organization (WHO) and other global organizations are seeking ways to increase the amount of information and access people have to contraception and other resources related to family planning all round the world. In many third world countries, rapid population growth and its attendant consequences have necessitated continuous search for suitable birth control methods. 
Combined oral contraceptive (COCs) pills contain both progestin and estrogen. The COCs are readily available and acceptable in developing countries to reduce population growth and to prevent morbidity and motality arising from unwanted pregnancies (John et al, 2008).fertilization from taking place. In some women, progestin inhibits ovulation (Beral, 1977). Administration of Oral Contraceptive (OC) steroids has been shown to increase plasma viscosity and haematocrit value (Lowe et al., 1980). Studies have also shown that low dose OC leads to no biologically meaningful changes in blood rheology, while higher than normal dose induce limitation of blood fluidity (Ernst et al., 1989).Several haemorheological and haemostatic parameters has been associated closely with hormone replacement therapy. Such parameters include blood viscosity, plasma viscosity, haematocrit value, fibrinogen level, fibrinolytic activity and thromboxane level (Moreau et al., 2003). Studies have shown that selective use of hormone therapy may alter these relationships with ageing (Moreau et al., 2003). Hormone therapy has also been shown to influence blood flow (Dinenno et al., 1999, 2001; Dunba et al., 2000; Moreau et al., 2003). In previous studies conducted in female rats and in women, COCs were found to induce a platelet hyperactivity that was related to an oxidative stress (Denis, 1997). Cases of megaloblastic anaemia have been reported to occur in women taking COCs (Clarke et al., 1991). Administration of COCs has been shown to increase plasma viscosity (Persico et al., 2004; Manchiel et al., 2005) and haematocrit value (Lowe et al., 1980).Estrogen inhibits the production of erythropoiesis stimulating factor (ESF). It was suggested that estrogens inhibit erythropoiesis by suppressing the production of an extrarenal precursor of ESF (Edwin et al.). Linda et al. (1981) report that estrogen decreases concentration of erythropoietin-responsive cells (ERC) in the marrow. They further state that estrogen suppresses only the early stages of erythroid proliferation and/or differentiation by a mechanism involving possibly the stromal cells of the marrow microenvironment.

\section{MATERIALS AND METHODS:}

The combined oral contraceptive used is DUEFEM®. They were obtained from family clinic, Ahmadu Bello University Teaching Hospital, Shika-Zaria, and from the Societyfor Family Health (SFH) Abuja, Nigeria. COCs DUOFEM ${ }^{\circledR}$ tablets which combined ethinyl estradiol and Norgestrel were manufactured by Wyeth Ayerst (USA) and packed and marketed by the Society for Family Health, Lagos, Nigeria. DUOFEM® is a child spacing pill containing ferrous fumarate tablets. Each DUOFEM cycle contains 28 pills; each white tablet contains $0.3 \mathrm{mg}$ Norgestrel and $0.03 \mathrm{mg}$ Ethinglestradiol and each brown tablet contains $75 \mathrm{mg}$ ferrous fumarate. DUOFEM ${ }^{\circledR}$ has a molecular weight of $312.4458 \mathrm{~g} / \mathrm{mol}$. DUEFEM is available in $0.75 \mathrm{mg}$ tablets. Twenty-one (21) tablets of the drug were dissolved in $100 \mathrm{ml}$ of distilled water. The drug was given daily by oral gavage syringe. $0.6 \mathrm{ml} / \mathrm{kg}$ of the drug was given for every four days.

Eighty (80) female wistar rats aged 10-12 weeks weighing 180-250 g were used for the study. They were divided into four groups of 20 rats each comprising 10 treated and 10 control rats.

[1] Group 1: Received COCs (DUOFEM®) $0.6 \mathrm{mg} / \mathrm{kg}$ body weight for 9 oestrous cycles (36 days).

[2] Group 2: Received COCs (DUOFEM®) $0.6 \mathrm{mg} / \mathrm{kg}$ body weight for 12 oestrous cycles (48 days).

[3] Group 3: Received COCs (DUOFEM®) $0.6 \mathrm{mg} / \mathrm{kg}$ body weight for 15 oestrous cycles (60 days).

[4] Group 4: Received COCs (DUOFEM®) $0.6 \mathrm{mg} / \mathrm{kg}$ body weight for 18 oestrous cycles (72 days).

The COC was given intragastically in 5-day cycles (4-day treatment with 1-day break). All controls were given fresh water at ad libitum daily for the period of the experiment. Experimental animals in the study were treated in accordance with the National Protection Laws of Animal Welfare. A haematology analyzer was used to perform a complete blood count (CBC or FBC). It carries out quantitative and qualitative analyses of red and white blood cells and of platelets (erythrocytes, leukocytes and thrombocytes).

III. RESULTS:

Table 1: The effects of combined oral contraceptives on some haematological parameters in female wistar rats

\begin{tabular}{llllll}
\hline Groups & Hb $(\mathbf{g} / \mathbf{d l})$ & PCV $(\boldsymbol{\%})$ & $\begin{array}{l}\text { RBC } \\
(\times 1012 / L)\end{array}$ & $\begin{array}{l}\text { WBC } \\
(\times 109 / \boldsymbol{L})\end{array}$ & $\begin{array}{l}\text { Platelet } \\
(\times 109 / \boldsymbol{L})\end{array}$ \\
\hline A (36 Days) & $12.3 \pm 1.2$ & $38.5 \pm 2.1$ & $6.1 \pm 07$ & $6.1 \pm 1.3$ & $783.6 \pm 13.9$ \\
Control & $15.5 \pm 0.6$ & $48.7 \pm 1.0$ & $7.9 \pm 0.6$ & $9.5 \pm 0.8$ & $821.4 \pm 11.4$ \\
P-value & 0.001 & 0.002 & 0.001 & 0.003 & 0.153 \\
B (48 Days) & $12.1 \pm 1.2$ & $36.0 \pm 2.0$ & $6.0 \pm 0.8$ & $5.3 \pm 1.6$ & $559.0 \pm 12.6$ \\
Control & $14.6 \pm 0.7$ & $43.6 \pm 1.5$ & $7.3 \pm 0.4$ & $8.5 \pm 1.1$ & $691.4 \pm 11.0$ \\
P-value & 0.009 & 0.017 & 0.007 & 0.041 & 0.133 \\
C (60 Days) & $13.0 \pm 0.9$ & $40.4 \pm 1.5$ & $6.6 \pm 0.7$ & $6.7 \pm 1.8$ & $508.2 \pm 11.1$ \\
Control & $13.5 \pm 0.8$ & $42.8 \pm 1.6$ & $6.6 \pm 0.6$ & $5.8 \pm 0.9$ & $629.2 \pm 12.9$ \\
P-value & 0.046 & 0.002 & 0.969 & 0.560 & 0.232 \\
D (72 Days) & $11.5 \pm 0.8$ & $34.2 \pm 1.4$ & $5.8 \pm 0.9$ & $7.2 \pm 1.4$ & $660.6 \pm 10.8$ \\
Control & $13.6 \pm 0.6$ & $40.9 \pm 0.9$ & $6.8 \pm 0.7$ & $9.7 \pm 1.0$ & $642.2 \pm 10.5$ \\
P-value & 0.001 & 0.068 & 0.068 & 0.041 & 0.437 \\
\hline
\end{tabular}


Dynamics Of Combined Oral...

Table 2: The effects of combined oral contraceptives on some haematological parameters in female wistar

\begin{tabular}{|c|c|c|c|c|c|c|c|c|c|}
\hline Groups & $\mathbf{N}(\%)$ & L (\%) & M (\%) & E (\%) & B (\%) & $\begin{array}{l}\text { MPV } \\
\text { (fl) }\end{array}$ & $\begin{array}{l}\text { MCV } \\
\text { (fl) }\end{array}$ & $\begin{array}{l}\mathrm{MCH} \\
\text { (pg) }\end{array}$ & $\begin{array}{l}\text { MCHC } \\
\text { (g/dl) }\end{array}$ \\
\hline A (36 Days) & $\begin{array}{l}15.6 \pm 2 . \\
0\end{array}$ & $76.4 \pm 2.4$ & $4.6 \pm 1.2$ & $3.0 \pm 1.1$ & $\begin{array}{l}0.1 \pm 0 . \\
1\end{array}$ & $6.4 \pm 0.6$ & $\begin{array}{l}58.5 \pm 1 \\
4\end{array}$ & $19.0 \pm 0.7$ & $32.4 \pm 0.6$ \\
\hline Control & $9.6 \pm 1.2$ & $83.6 \pm 1.8$ & $3.2 \pm 1.1$ & $3.4 \pm 1.2$ & $\begin{array}{l}0.2 \pm 0 . \\
1\end{array}$ & $6.5 \pm 0.4$ & $\begin{array}{l}60.8 \pm 1 \\
7\end{array}$ & $19.5 \pm 0.8$ & $31.5 \pm 0.7$ \\
\hline P-value & 0.001 & 0.050 & 0.156 & 0.056 & 0.164 & 0.840 & 1.000 & 0.221 & 0.038 \\
\hline B (48 Days) & $\begin{array}{l}16.8 \pm 2 . \\
6\end{array}$ & $70.4 \pm 2.7$ & $9.0 \pm 1.4$ & $3.2 \pm 1.1$ & $\begin{array}{l}0.3 \pm 0 . \\
1\end{array}$ & $6.6 \pm 0.4$ & $\begin{array}{l}59.0 \pm 1 \\
6\end{array}$ & $20.1 \pm 0.9$ & $33.8 \pm 1.0$ \\
\hline Control & $\begin{array}{l}14.8 \pm 2 . \\
0\end{array}$ & $76.8 \pm 1.5$ & $4.8 \pm 1.6$ & $3.2 \pm 1.1$ & $\begin{array}{l}0.3 \pm 0 . \\
1\end{array}$ & $6.4 \pm 0.4$ & $\begin{array}{l}59.1 \pm 1 \\
4\end{array}$ & $20.4 \pm 0.9$ & $33.9 \pm 0.7$ \\
\hline P-value & 0.043 & 0.113 & 0.023 & 0.179 & 0.165 & 0.400 & 0.985 & 0.628 & 0.869 \\
\hline C (60 Days) & $\begin{array}{l}10.2 \pm 1 \text {. } \\
2\end{array}$ & $83.6 \pm 1.6$ & $3.8 \pm 1.1$ & $2.0 \pm 0.8$ & $\begin{array}{l}0.2 \pm 0 . \\
1\end{array}$ & $6.8 \pm 0.7$ & $\begin{array}{l}61.0 \pm 1 . \\
5\end{array}$ & $19.7 \pm 0.6$ & $32.4 \pm 0.7$ \\
\hline Control & $\begin{array}{l}17.0 \pm 2 . \\
8\end{array}$ & $75.2 \pm 2.9$ & $4.2 \pm 1.1$ & $3.2 \pm 1.1$ & $\begin{array}{l}0.3 \pm 0 . \\
1\end{array}$ & $6.6 \pm 0.6$ & $\begin{array}{l}64.5 \pm 1 \\
3\end{array}$ & $20.3 \pm 0.8$ & $31.5 \pm 0.7$ \\
\hline P-value & 0.050 & 0.077 & 0.641 & 0.002 & 0.147 & 0.102 & 0.031 & 0.156 & 0.030 \\
\hline D (72 Days) & $\begin{array}{l}14.8 \pm 2 . \\
1\end{array}$ & $73.4 \pm 2.2$ & $5.8 \pm 1.3$ & $3.4 \pm 1.0$ & $\begin{array}{l}0.1 \pm 0 . \\
1\end{array}$ & $6.2 \pm 0.5$ & $\begin{array}{l}59.6 \pm 1 \\
4\end{array}$ & $18.8 \pm 0.5$ & $31.7 \pm 0.8$ \\
\hline Control & $\begin{array}{l}12.0 \pm 2 . \\
0\end{array}$ & $78.2 \pm 1.7$ & $5.4 \pm 1.3$ & $3.8 \pm 1.1$ & $\begin{array}{l}0.2 \pm 0 . \\
1\end{array}$ & $6.3 \pm 0.7$ & $\begin{array}{l}61.6 \pm 1 . \\
2\end{array}$ & $18.8 \pm 0.8$ & $33.0 \pm 1.0$ \\
\hline P-value & 0.008 & 0.105 & 0.744 & 0.695 & 0.125 & 0.675 & 0.120 & 0.959 & 0.062 \\
\hline
\end{tabular}

Haemoglobins: There was a significant decrease in $\mathrm{Hb}$ levels in all the treated group (A, B, C \& D) compared to the controls $(\mathrm{P}<0.001)$. The lowest value was seen in group $\mathrm{D}$ (72 days) (Table 1$)$.

PCV was significantly reduced in treated groups A (36 days), B (48 days) and C (60 days) compared to the controls $(\mathrm{P}<0.002, \mathrm{P}<0.017, \mathrm{P}<0.002)$. There was no significant change in $\mathrm{PCV}$ in group $\mathrm{D}(72$ days $)$ compared to the control $(\mathrm{P}<0.068)$ (Table 1).

RBC Count: There was a significant decrease in RBC count in treated groups A (36 days) and B (48 days), compared to the controls $(\mathrm{P}<0.001, \mathrm{P}<0.007)$. There was no significant change in $\mathrm{RBC}$ count in treated groups $\mathrm{C}$ (60 days) and $\mathrm{D}$ (72 days) compared to the controls $(\mathrm{P}<0.969, \mathrm{P}<0.068)$ (Table 1$)$.

WBC was significantly decreased in treated groups A (36 days), B (48 days) and D (72 days) compared to the controls. There was not significant change in WBC count in treated group $\mathrm{C}$ (60 days) $(\mathrm{P}<0.560)$ (Table 1).

Platelet: There was no significant change in platelet counts in all the treated groups compared to the controls (Table 2).

Neutrophils: There was a significant increase in neutrophil counts in all the treated groups compared to the controls $(\mathrm{P}<0.001)$ (Table 2).

Lymphocytes: There was significant decrease in lymphocyte count in group A (36 days) compared to the control $(\mathrm{P}<0.05)$ (Table 2).

There were no significant changes in lymphocyte counts in the treated groups B (48 days), C (60 days) and D (72 days) compared to the controls (Table 2).

Monocytes: There was no significant change in monocyte counts in treated groups A (36 days), C (60 days) and D (72 days) compared to the controls. There was a significant increase in monocyte count in group B (48 days) compared to the control $(\mathrm{P}<0.023)$ (Table 2$)$.

Eosinophils: There was a significant decrease in eosinophil count in group C (60 days) compared to the control $(\mathrm{P}<0.002)$ (Table 2).

There were no significant changes in eosinophils in groups A (36 days), B (48 days) and D (72 days) compared to the controls (Table 2).

Basophils: There was no significant change in basophil counts in all the treated groups compared to the controls $(\mathrm{P}<0.164, \mathrm{P}<0.165, \mathrm{P}<0.147 \& \mathrm{P}<0.125)$ (Table 2). 
Mean platelet volume (MPV): There were no significant changes in MPV in all the treated groups compared to the controls (Table 2).

Mean cell volume (MCV): There was significant decrease in treated groups A (36 days) and C (60 days) compared to the controls (Table 2).

There were no significant decreases in MCV in treated groups B (48 days) and D (72 days) compared to the controls (Table 2).

MCH: There was no significant decrease in all the treated groups compared to the controls (Table 2).

MCHC: MCHC was increase in treated groups A (36 days) and C (60 days) compared to the controls (Table 2). There was no significant increase in treated groups B (48 days) and D (72 days) compared to the controls (Table 2).

\section{DISCUSSION:}

In this study the effect of COC on haematological and biochemical parameters in female wistar rats was investigated. The result shows a reduction in haemoglobin $(\mathrm{Hb})$, Packed cell volume(PCV), Red blood cell (RBC), White blood cell (WBC) counts and lymphocytes in all the groups that were given COC, compared to the controls in each group ( $\mathrm{P}<0-05)$. The finding of lower Hb, PCV, RBC, WBC and Lymphocytes agrees with the finding of Sajida et al. (2006). The finding is however contrary to that of other investigators like Bulur et al. (2006), Babatunde et al. (2003) and Abdalla (2008), who reported no changes in full blood count in women on COC. The least values of $\mathrm{Hb}, \mathrm{PCV}$ and RBC were found in group D (72 days). It could be that the use of COC for a longer period may lead to anaemia. The finding of lower $\mathrm{Hb}, \mathrm{PCV}$ and RBC counts in COC treated groups compared to controls may be as a result of the haemodilutary effect of estrogen and the effect of estrogenon the cytokines like IL-11 and IL-6. The findings of lower values of WBC counts in COC treated groups suggest that prolong use of COC may lower the immunity of the users.

The findings of lower WBC count in COC treated groups was in agreement with that of Sajida et al. (2006), and contrary to the findings of Surasak et al. (2007) who observed no changes in WBC count and that of Araz et al. (2009) who observed increase in WBC count in COC treated female wistar rats. The difference may be as a result of the use of different COC with different concentration of estrogen and progesterone and the duration of use. There was no significant changes observed in COC treated groups in platelet counts and mean platelet volume (MPV) compared to the controls. This finding agrees with that of Surasak et al. (2007), Peter (2013), Bulur et al. (2006) and Babatunde et al. (2003). The observation was however contrary to that of Sajida et al. (2006) who reported significant increase on MPV in subjects on COC. Estrogen therapy especially with high doses of synthetic estrogen in COCs has been shown to increase platelet count and platelet aggregation, to enhance cloth formation increasing the incidence of thromboembolic disease (Meade et al., 1980). Low platelet count may reduce the risk of thrombosis.

There was no significant change in $\mathrm{MCV}, \mathrm{MCH}$, Neutrophil, Eosinophil and Basophil counts in COC treated groups compared to the controls. This finding is in agreement with that of Peter (2013), Bulur et al. (2006) and Babatunde et al. (2013), and contrary to the findings of Sajida et al. (2006) and Araz et al. (2009). Neutrophil count was observed in this study. These findings agree with that of Araz et al. (2009). In general, the use of COC in female wistar rats suppressed haemopoiesis in this study resulting in lowering of $\mathrm{Hb}, \mathrm{PCV}, \mathrm{RBC}$ and WBC counts.

\section{CONCLUSION:}

COCs have evolved from one generation to another. The COC (DUOFEM) used in this study is a third generation COC. Much emphasis has been laid on the reduction of the concentration of estrogen and progesterone. Even at the lowest concentration of estrogen and progesterone in DUOFEM, the safety of COC is yet to be achieved This study has challenged the concept that reducing the doses of both estrogen and progesterone in COCs may eliminates the risks associated with it uses.COC users should be monitored for haematological parameters.

\section{REFERENCES}

[1] Abdalla T.M., Kordofani A.A.Y., Nimir A.A.H. (2008). Haemostatic studies in Sudanese women on oral contraceptive pills. Khartoum Medical Journal, 1(3): 116-118.

[2] Ahmed J. Al-Husaynee and Muna A. Kashmona (2007). Effect of combined oral contraceptive pills on some haemostatic parameters. Annals of the College of Medicine Mosul, 33(1 \& 2): 66-69.

[3] Akhigbe R.E., Azeez M.O., Ige S.F., Oyeyipo L.P., Ajao F.O. and Alade A.O. (2008). Haematological effects of long-term administration of combined oral contraceptive in rats. International Journal of Pharmacology, 4(5): 403-406. 
[4] Almedia-Porada G., Porada C.D. and Chamberlain J. (2004). Formation of human hepacyte by human haemopoietic stem cells in sheep. Blood, 104: 2582-2590.

[5] Babatunde A.S. and Olatunji P.O. (2004). Short-term effect of oral contraceptive pills on some haemostatic parameters in healthy Nigerian women. Niger. Postgrad. Journal, 11(4): 246-250.

[6] Bernadette F.R., Gorge A.F. and Eliane M.K. (2012). Haematology: clinical principles and applications (4 $4^{\text {th }}$ Ed.). China: Elsevier Saunders.

[7] Bulur S., Albayrak M., Bulur S., Keskin F., Köse S.A., Aslantas Y., Türker Y. and Ozhan H. (2012). Effect of combined oral contraceptive use on platelet volume in women at reproductive age. Clin. Exp. Obstet. Gynecol., 39(3): 314-316

[8] Jayachandran M. and Miller V.M. (2003). Human platelets contain estrogen receptor $\alpha$, caveolin-1 and estrogen receptor associated proteins. Platelets, 14: 75-81.

[9] Jick S.S. and Hernandez R.K. (2011). Risk of non-fatal venous thromboembolism in women

[10] Monjok E., Adrea S., and John E. (2010). Contraceptive practices in Nigeria. Centre for Disease Control and Preventive (CDC). Family planning methods and practice, Africa. $2^{\text {nd }}$ Ed. Atlanta, Georgia: Division of Reproductive Health, 295-337.

[11] Olatunji, L.A., Owoeye J.F.A., Olatunji V.A., and Soladoye A.O. (2005). Effect of acute folic acid ingestion on blood pressure, haemorheological and plasma lipid variables in healthy young men, Nig. J. Health Biomed.Sci. 4: 117-120

[12] Peter U.O. (2013). Women use of oral contraceptives - does it have any effect on haematological parameters? Annals of the College of Medicine, $33(1 \& 2)$

[13] Rosing J., Curvers J., and Tans G. (2001). Oral contraceptives, thrombosis and haemostasis. Obstet. Gynecol. Reprod. Biol, (2): 193197

[14] Sajida S.H., Al-Chalaby S.M.T. and Amjad F.A. (2006). Effect of oral contraceptive pills on haematological indices. Tikrit Medical Journal, 12(1): 65-69.

[15] Sembulingam K., Sembulingam P. (2006). Essentials of medical physiology $\left(4^{\text {th }}\right.$ Ed.). New Delhi, India: Jaypee Brothers

[16] Shojana A.M. (1982). Oral contraceptive effects on folate and vitamin B-12 metabolism. Can. Med. Assoc. J. 126: 244-247. 